University of Louisville

ThinkIR: The University of Louisville's Institutional Repository

Electronic Theses and Dissertations

$1-1926$

\title{
The effects of ice cream in the diet of young life.
}

Mildred A. Schneiderhan

University of Louisville

Follow this and additional works at: https://ir.library.louisville.edu/etd

\section{Recommended Citation}

Schneiderhan, Mildred A., "The effects of ice cream in the diet of young life." (1926). Electronic Theses and Dissertations. Paper 1277.

https://doi.org/10.18297/etd/1277

This Master's Thesis is brought to you for free and open access by ThinkIR: The University of Louisville's Institutional Repository. It has been accepted for inclusion in Electronic Theses and Dissertations by an authorized administrator of ThinkIR: The University of Louisville's Institutional Repository. This title appears here courtesy of the author, who has retained all other copyrights. For more information, please contact thinkir@louisville.edu. 


\author{
UNIVERSITY OF LOUISVILJE \\ THE EFFECTS OF ICE CREAM IN THE \\ DIET OF YOUIG LIFE \\ A DISSERTATION \\ SUBUITTED TO THE FACULPY OF \\ THE GRADUAIE SCHOOL OF LIBERAL ARTS \\ IN PARTIAL FULFILLMENTS OF THE \\ REQUIRHMENTS FOR THE DEGREE \\ OF WASTER OF SCIENCE \\ DEPARTMENI OF CHEIISTRY.
}

by

MILDRED A. SCHIVIDERHAIV.

1926 
THE EFFECTS OF ICE CREAM IN THE DIET OF YOUNG LIFE. 
INTRODUCTION. 
Much work has been done in the past on the nutritional value in young life of different dairy products, all of which experiments have been carried to successful completion by various men at different times.

There is, however, no published information demonstrating the comparative values resulting from experimental work in the nutritional value of ice crean as a supplementary diet in infant life.

For the purpose of the following experiments, the albino rat, (Mus Norvegicus Albinus) and the Norway rat, (Mus Norvegicus), together with cuinea Pigs and cats were used.

It is a well known fact that rats exhibit the same sensitivity to surrounding conditions to which they are subjected as does man, and likewise that they respond to these conditions in a like manner.

They are, therefore, ideal subjects for nutritional experimentation.

The life of the Albino Rat and the Norway is three and four years respectively, while the average old-age possibilities of man is approximately ninety years. The body composition and the composition of the kidney secretion of the rat are exact in percentage to that of man. Therefore, multilpying the results of these experiments will give the results to be gained for man. It is the purpose of this paper to show the relative nutritional value of ice cream in young life, as demonstrated by simultaneous experiments. 
EXPERIMENTAL. 
The rats used in experiment one were two litters pf Albino Rats, one litter containing nine individuals, the other, ten. The litters were from two pairs of pure bred Albino Rats and were separated from their respective mother immediately before the weaning period.

The rats were separated and placed in individual, sanitary cages when they were three weeks and four days old. Their weights were taken weekly and all changes in appearances were carefully observed and tabulated.

The rats were all subjected to the same conditions of environment and temperatures. Each rat was given all the parti= cular diet it could eat, and the amount of food which it ingested was carefully noted.

The first litter consisting of ten subjects was separated into two groups of five each and were fed on the following diet :

\section{GROUP ONE}

Rat \#1- Fresh Milk and White Bread Soaked in Water

Rat

Rat

Rat

$\# 2-$
$\# 3-$
$\#-4$
$\# 5-$

Rat \#5- "

$\begin{array}{lllllll}\text { " } & \text { " } & \text { " } & \text { " } & \text { " } & \text { " } \\ \text { " } & \text { " } & \text { " } & \text { " } & \text { " } & \text { " } & \text { " }\end{array}$

\section{GROUP TWO}

Rat \#6- Ice Cream and White Bread Soaked in Water Rat Rat Rat \#7\$8Rat \#10 "

$\begin{array}{ccccccc}\text { Cream } & \text { and } & \text { White } & \text { Bread } & \text { Sorked } & \text { in } & \text { Water } \\ \text { " } & \text { I } & \text { " } & \text { " } & \text { " } & \text { " } & \text { " } \\ \text { "I } & \text { " } & \text { " } & \text { " } & \text { " } & \text { " } & \text { " } \\ \text { " } & \text { " } & \text { " } & \text { " } & \text { " } & \text { " } & \text { " } \\ \text { " } & \text { " } & \text { " } & \text { " } & \text { " } & \text { " } & \text { " }\end{array}$


The second litter consisting of nine subjects

was separated into two groups of five and four individuals each, which were fed on the following diets, respectively:

\section{GROUP THREE}

Rat \#11- Ice Cream and Fresh Milk

Rat \#12- " " " " "

Rat \#13- " " " " "

Rat \#14- " " " "

Rat \#15- " " "

GROUP FOUR

Rat \#16- Ice Cream, Fresh Milk, White Bread Soaked in Water Rat \#17- " " " " " " Rat \#18- " " " Rat \#19- " "

The weights of all rats fed on the same diets are given on the same page following, and comparisons in rate of growth are made by means of a chart showing the best rat from each group. 


\begin{tabular}{|c|c|c|c|c|c|}
\hline & $\begin{array}{l}\text { Rat \#1 } \\
\text { Male }\end{array}$ & $\begin{array}{l}\text { Rat \#2 } \\
\text { Female }\end{array}$ & $\begin{array}{l}\text { Rat \#3 } \\
\text { Female }\end{array}$ & $\begin{array}{l}\text { Rat \#4 } \\
\text { Male }\end{array}$ & $\begin{array}{l}\text { Rat \#5 } \\
\text { Male }\end{array}$ \\
\hline Nov. 2 & $52 \mathrm{gms}$ & $46 \mathrm{gms}$ & $52 \mathrm{gms}$ & $55 \mathrm{gms}$ & $59 \mathrm{gms}$ \\
\hline " 8th & 74.4 & 67.4 & 73.3 & 74.9 & 78.9 \\
\hline " $15 \mathrm{th}$ & 89 & 88.7 & 96.2 & 106.9 & 86.1 \\
\hline " 22nd & 110.4 & 108.5 & 110.1 & 122 & 114.9 \\
\hline " 29th & 135.5 & 119 & 128.8 & 142.1 & 137.7 \\
\hline Dec 6 & 141 & 126 & 136.2 & 160 & 154 \\
\hline " $13 \mathrm{th}$ & 141.8 & 136.2 & 144 & 170 & 170 \\
\hline "20th & 151.4 & 133.5 & 147.4 & 159.5 & 160.9 \\
\hline & $\begin{array}{l}\text { Rat \#6 } \\
\text { Female }\end{array}$ & $\begin{array}{l}\text { Rat } \# 7 \\
\text { Female }\end{array}$ & $\begin{array}{l}\text { Rat \#8 } \\
\text { Female }\end{array}$ & $\begin{array}{l}\text { Rat \#9 } \\
\text { Male }\end{array}$ & $\begin{array}{l}\text { Rat \#10 } \\
\text { Male }\end{array}$ \\
\hline Nov $\cdot 2$ & $55 \mathrm{gms}$ & $57 \mathrm{gms}$ & $51 \mathrm{gms}$ & $62 \mathrm{gms}$ & $52 \mathrm{gms}$ \\
\hline " $8 \mathrm{th}$ & 74.7 & 87.1 & 70 & 87.7 & 77.6 \\
\hline " 15th & 91.1 & 104.5 & 88.5 & 117 & 111.6 \\
\hline "2and & 106.7 & 120.4 & 105.8 & 116.6 & 133.4 \\
\hline " 29 th & 127 & 134 & 120 & $117 \cdot 5$ & 133.8 \\
\hline Dec. 6 & 138.7 & 146.1 & 128.8 & 133 & 156.6 \\
\hline " 13th & 141.4 & 146.8 & 137.8 & 133 & 179 \\
\hline " 20th & 148.8 & 162.6 & 147.3 & 159.3 & 188.3 \\
\hline
\end{tabular}




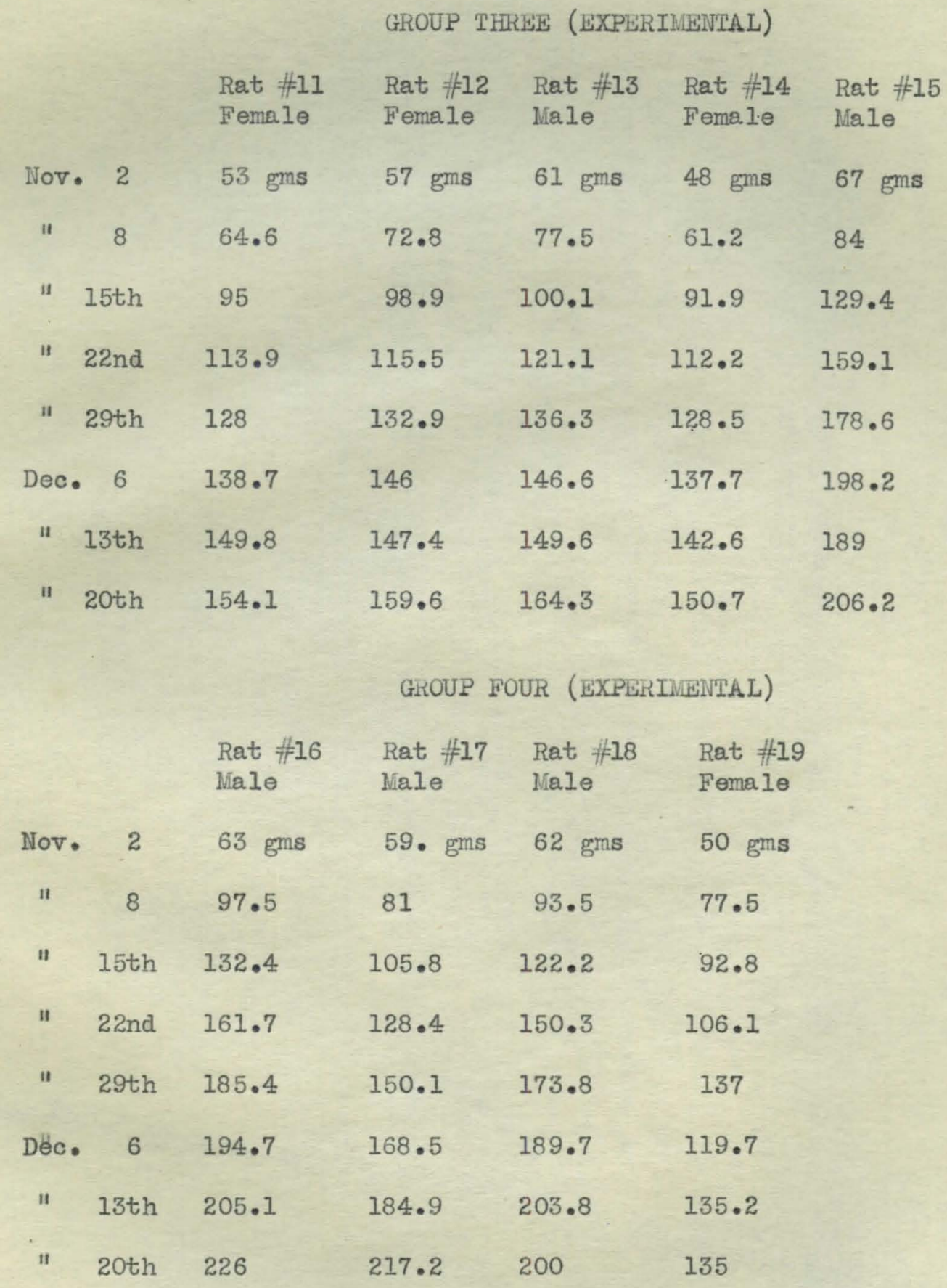




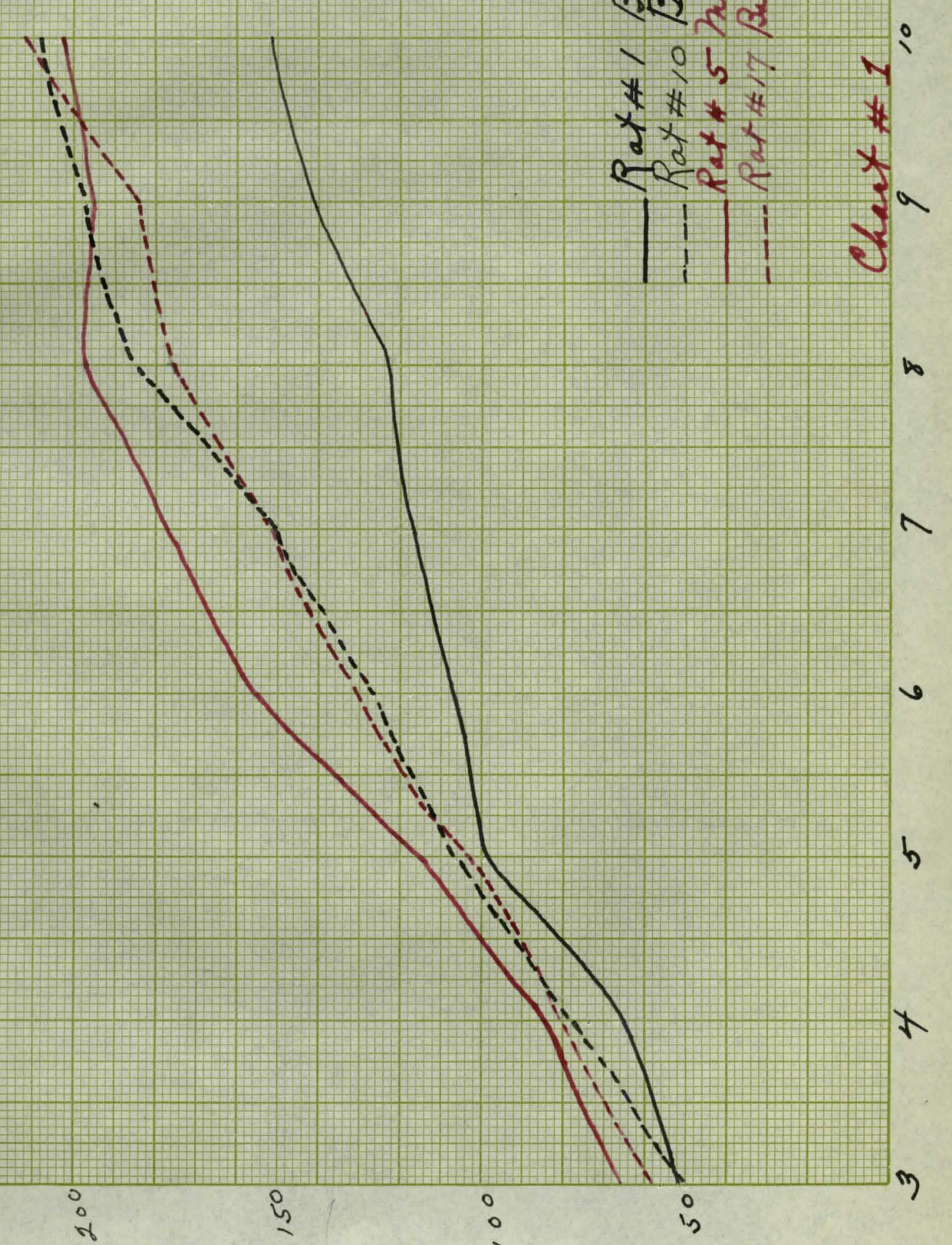


Rats numbers three and five were bred together for two weeks. The female was fed for the entire gestation period on a table scrap diet and ice cream. Four rats were born on March $3 r d$. One rat died the second day.

At the end of three weeks - the remaining three rats were separated and placed in individual. sanitary cages, and weighed thereafter, weekly. In each case, each subject was given all the food in the particular diet it could eat and each was subjected to the same conditions of environment and temperatures.

They were put into two groups of two and one, respectively, and fed on the following diets:

\section{GROUP ONE}

Rat \#2I- Fresh Milk and White Bread Soaked in Water GROUP TWO

Rat \#22- Fresh Milk, Bread Soaked in Water and Ice Cream Rat \#23-

The weights of these rats are given on the following page for comparison, and a chart is also given to show the rate of growth of rats numbers twenty-one and twenty-three. 


\section{GROUP ONE (CONTROL)}

Rat \#21- Female

$\begin{array}{ccc}\text { Mch. 24th } & 45.5 \\ \text { " } & \text { 28th } & 55.4 \\ \text { Apr. 4th } & 63.8 \\ \text { " } & \text { 11th } & 71.2 \\ \text { " } & \text { 18th } & 81.5 \\ \text { " } & \text { 25th } & 90.7 \\ \text { liay } & \text { 2nd } & 110.0 \\ \text { " } & \text { 9th } & 129.3\end{array}$

GROUP TWO (EXPERIMENTAL)

Rat \#22- Female Rat \#23- Nale.

Wch. 24th 36 gms

$46.4 \mathrm{gms}$

" 28th 67

79

Apr. 4th 80

$95 \cdot 1$

111th 85

100.1

11 18th 98.2

114.6

i 25 th 117.3

$132 \cdot 5$

May 2nd 136.5

170

$\begin{array}{lll}1 & 9 t h \quad 146\end{array}$

194.5 
The Guinea Pigs used in this experiment were desecndents of the same litter.

When they were two weeks old, the four young were separated into two troups of two and two, each, weighed once each week, and all changes in appearance were carefully observed and noted.

They were fed on the following diets:

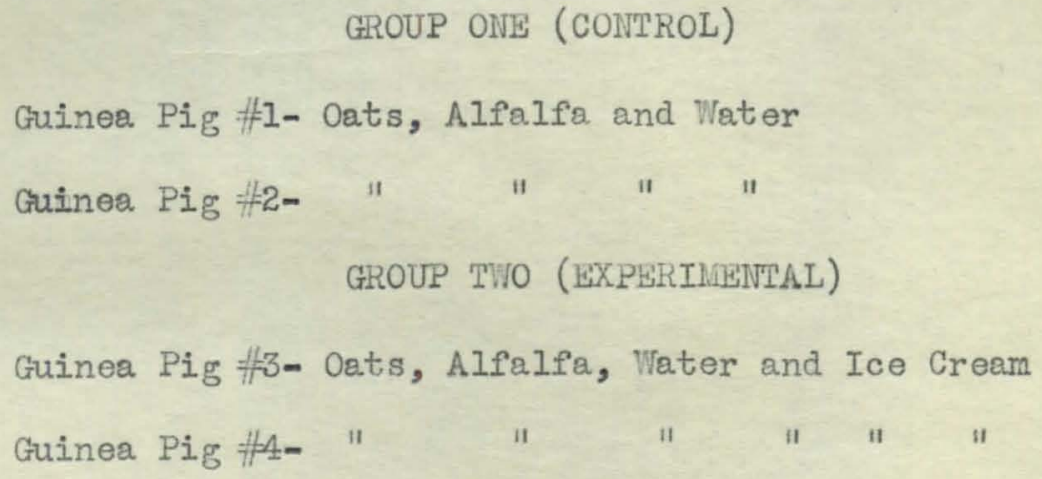




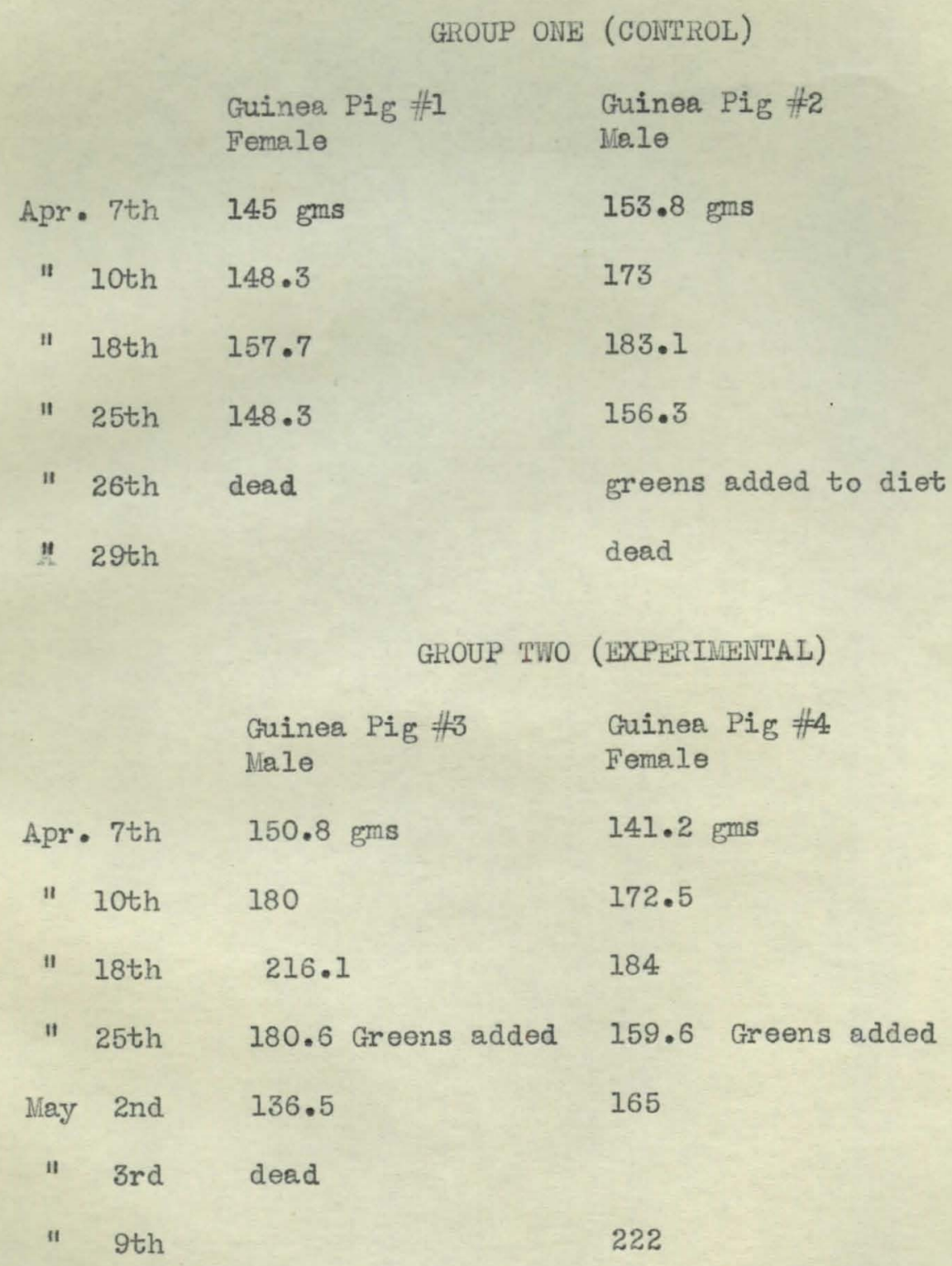




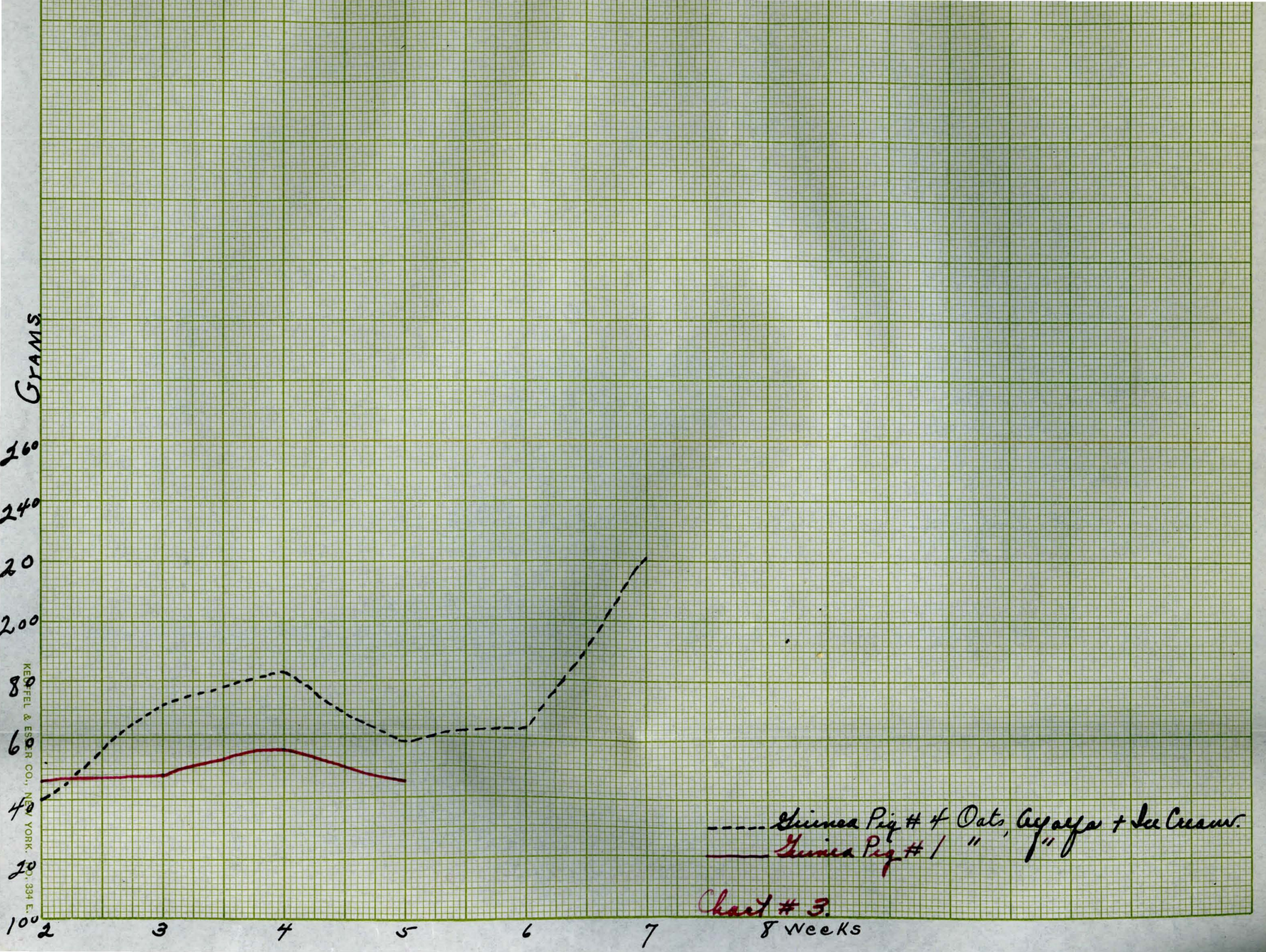


On April twentieth, the two Guinea Pigs in group one showed evidences of Scurvy. On April twenty-sixth, Guinea Pig number two, died, exhibiting all the external symptoms of advanced Scurvy.

There was added immediately to the diets of the three remaining Guinea Pigs, fresh greens.

The other Guinea Pig in group one showed evidences of Scurvy on April twenty-second, and despite the fact that it ate plentifully of the greens it died on April twenty-ninth, evincing all the symptoms of advenced Scurvy with accompanying convulsions.

Likewise, in group two, Guinea Pig number three exhibited symptoms of Scurvy on April twenty-seventh. Upon addition of greens to the diet, the condition seemed to improve during the following three days. However, on May third, it died. Apparently, the metabolic processes were so weakened after the onslought of Scurvy that they could not rebuild themselves. Guinea Pig number four began losing weight on April twentieth. Four days later, greens were added to the died. On Nay second, there was an increase of 4.4 grams in weight from April twenty-fifth. On Nay fifth, there was an increase of 16 grams. The final weight taken was 222 grams.

These animals are of exceptional advantage in feeding experiments because of the fact that their digestive system is practically identical with that of hurnan beings. 


\section{EXPERIMENT INUMBER FOUR.}

As an added check on the work already performed, two young Persian cats were obtained for further ice cream experiments.

Both kittens were from the same litter. They were removed from the mother when they were five weeks old, immediate before the weaning period. They were placed in separate sanitary cages, weighed weekly, and fed on the following diets. Cat \#I- Bread Soaked in Water, Fresh Milk and Ice Cream.

Cat \#2- " " " "

Both cats were subjected to the same conditions of environment and temperatures, and care was given to give each animal all it could eat. The eyes were washed daily with a weak solution of boric acid, and the fur was combed daily. The table following shows the comparative weights obtained during the experiment:

\begin{tabular}{|c|c|c|c|}
\hline & & $\begin{array}{l}\text { Cat \#I } \\
\text { Male }\end{array}$ & $\begin{array}{l}\text { Cat } \# 2 \\
\text { Female }\end{array}$ \\
\hline Apr. & $24 t h$ & $405.5 \mathrm{gms}$ & $405 \mathrm{gms}$ \\
\hline May & 2nd & 420.8 & 420 \\
\hline$"$ & $9 t h$ & 481 & 470 \\
\hline u & $16 \mathrm{th}$ & 560 & 510 \\
\hline$" 1$ & $23 r d$ & 642 & 537.4 \\
\hline " & $30 t h$ & 74.0 & 553.1 \\
\hline
\end{tabular}


In order to check the experiments performed in groups two and three in the first experiment, four Norway Rats were obtained from the same litter, two males and two females.

Rats numbers seven and nine from group two, Experiment One were bred together for one week. On March twenty-ninth three young were born two of which died on the second day. When the one remaining rat was twenty-one days old, it was removed from the mother and together with the Four Norway Rats utilized for the following experiment.

The Norway Rats were removed from the mother when they were twenty-one days old, placed in separate cages and with the Albino Rat mentioned above, placed in two groups and fed on the following diets:

\section{GROUP ONE}

Rat \#24- Bread Soaked in Water and Ice Cream

\begin{tabular}{|c|c|c|c|c|c|c|}
\hline Rat \#25- & " & " & is & $\|$ & " & "1 \\
\hline Rat \#26- & " & $"$ & " & " & " & " \\
\hline
\end{tabular}

\section{GROUP TWO}

Rat \#27- Ice Cream and Milk

Rat \#28- " " "

The weights of all the rats were taken weekly and all changes in appearances carefully noted. They were all subjected to the same conditions of environment and temperatures, throughout. The weights of both groups are given on the following page for comparison: 


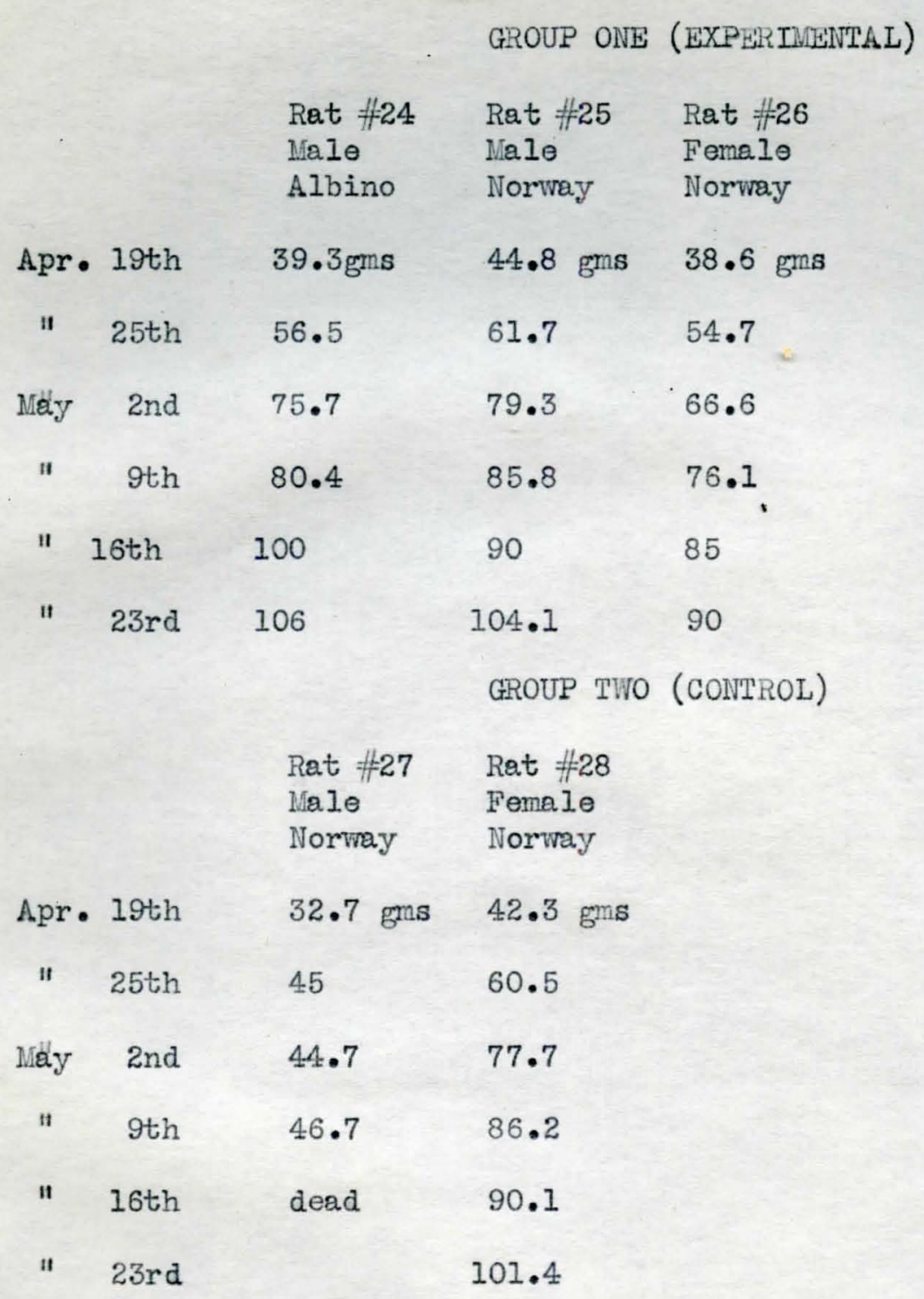

A chart showing the curve of growth of rats numbers twenty-four, twenty-five, and twenty-eight is given on the following page: 

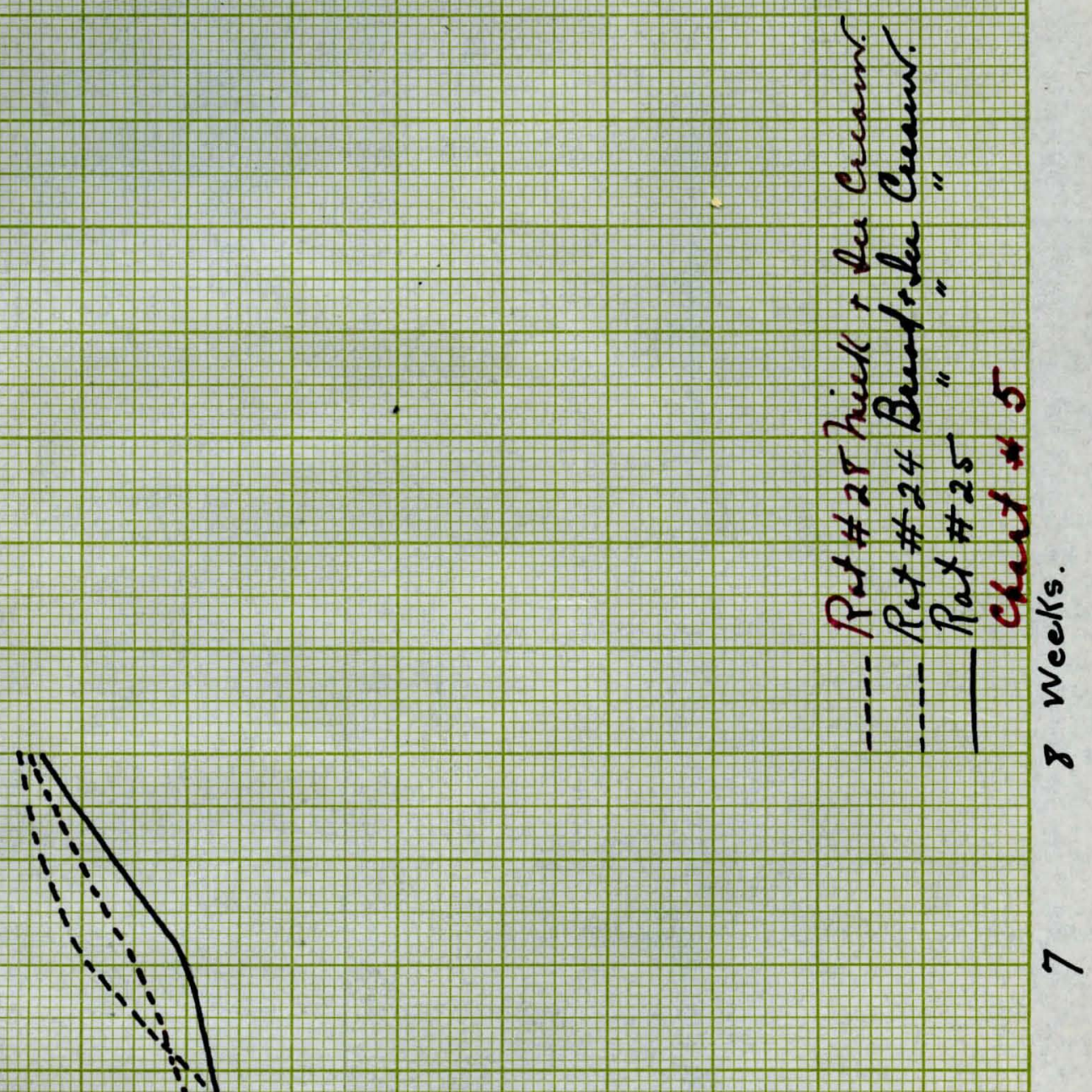

$\Lambda$

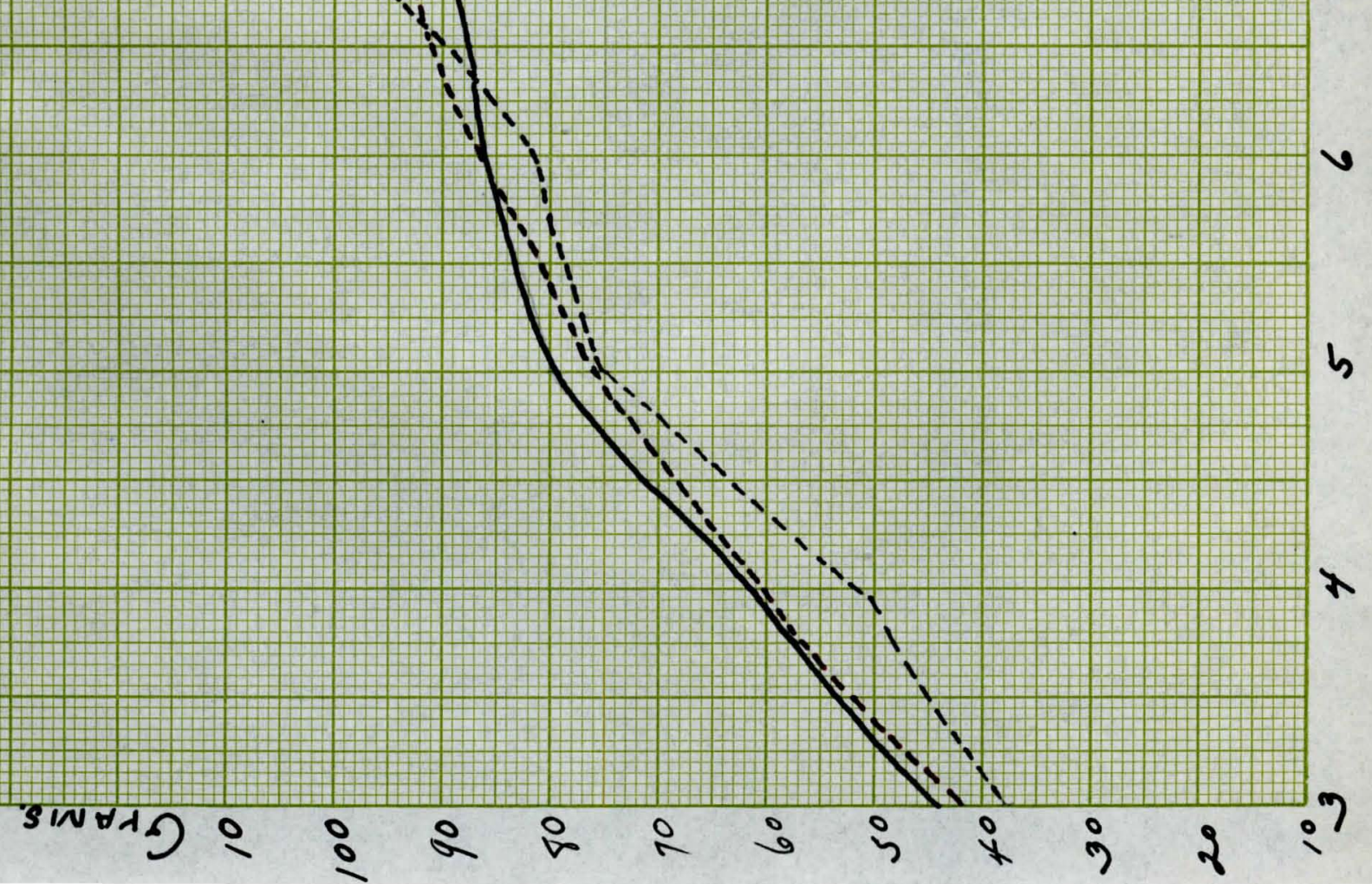


CONCLUSIONS 
The charts drawn to demonstrate graphically the results of these experiments show conclusively the relative nutritional vale of ice cream as a supplementary diet in young life.

During these experiments, the rats, both the Albino and the Norwogian shed practically no fur at all while on the experimental diets and at the same time, they exhibited unusual, healthy, normal activity.

The rats in groups two, three and four of Experiment One, and those in group two in Experiment Two, likewise those of groups one and two in Experiment Four developed an unusually long coat of fur of extraordinary texture and fineness and of continued whiteness.

In every case where ice cream was supplemented in the diet, the subject's rate of growth was more rapid. Each showed a consistant and steady rise in the curve of growth toward normal development as a result of increased body-building materials contained in the ice cream ingested. 


\section{REFERENCES}


THE EFFECTS OF DIFFERENT PERCENTAGES OF BUTTERFAT ON THE PHYSICAL PROPERTIES OF ICE CREAM. Research Bulletin \#70, Agricultural Experiment Station, Columbia, Missouri.

THE EFFECT ON THE VISCOSITY, BACTERIAL FLORA AND QUALITY OF RESULTING ICE CREAM MIXTURE WHEN REEMULSIFIED, REVISCOLIZED OR RE-HOMOGEIVIZED. Agricultural Experiment Station, Research Bulletin \#62, Columbia, Missouri.

- HOW ICE, CREAM APPEARS UNDER THE MICROSCOPE. by C. D. Dahle, Ice Cream Trade Journal, P. 69, February 1924.

EXPERIUENTAL STUDIES IN ICE CREAII DURING THE PAST YEAR. By R. C. Fisher, Ice Cream Review, P. 86, May 1924.

VISCOLIZING THE ICE CREAM MIXTURE. BY C. Z. GOssman, Creamery and Milk Plant Monthiy, P. 86, 1922.

THE EFFECTS OF SEVERAL INGREDIENTS USED IN THE MANUFACTURE OF COMMERCIAL ICE CREAM ON THE CHANGE IN TEMPERATURE DURING THE FREEZING PROCESS. Missouri Experiment Station, Research Bulletin $\# 71,1925$.

HONOGENIZATION. By R. Zsignomy and H. H. Spear, Chemistry of Colloids, P. 265, 1917.

FINDING A KEY TO VISCOSITY CONTROL. By A. C. Dalberg and J. C. Henning. Bulletin \#113, New York State Agricultura.1 Experiment Station.

THE FOOD VALUE OF EDIBLE GELETIN IN ICE CREAM. BY T. B. Downey, Ph. D., Industrial Fellow, Mellon Institute of Industrial Research, University of Pittsbery, Pittsburg, Pa. Food Technolog y and Engineering, July 1924.

FUTURE POSSIBILITIES FOR ICE CREAM. By A. D. Burke, Associate Professor of Dairying, Alabama State A. and M. CoIlege. Ice Cream Review, B.51, 1922.

FACTORS EFFECTING THE YIELD OF ICE CPEAM. Bulletin \#287, Purdue Agricultural Experiment Station, 1924.

WHAT THE SHRINKAGE TESTS REVEALED. By H. F. Judkins, Professor of Dairying, Massachusetts Agricultural College, Ice Cream Field, Nay 1926.

UNSOLVED PROBLENS OF BODY AND TEXTURE. BY C. D. Turnbow, Asst. Professor Dairy Industry, University of California, Ice Cream Trade Journal, July 1925. 